\title{
国立公園の環境に配慮した利用マナーに対する利用者の態度
}

\section{Visitors' attitude to environment friendly manner for conservation in national park}

\author{
小林 昭裕
}

\author{
Akihiro KOBAYASHI
}

\begin{abstract}
Based on the data obtained from self-administered mail-back questionnaires to visitors in Shiretoko and Daisetsuzan national parks, this study was conducted in order to improve visitors' behavior for conserving environmental condition in national park. Results of the survey of visitors' perception, practice and sense of burden to environment friendly manner were discussed by referring to two social psychological models which were "the decisions making model of environment conscious behavior" and "the dual-process of reactive and intentional decision-making". There were a few visitors who had sense of burden to environment friendly manner. However, those who didn't practice environment friendly manner sensed more burden to do it. There were difffernt tendencies of visitors' perception and practice between the two case study areas. Accoding to the pros and cons of visitors' perception, practice and sense of burden, classified eight types of combination gave several suggestions for changing visitors' perception and altering their behavior. Attitude toward environment friendly manner varied with age or occupation. In order to get much more visitors to practice environment friendly manner, we need to create strategies from social psychological views into the properties of classified visitors' attitude.
\end{abstract}

Keywords: behavior, manner, visitor, environment friendly, national park, perception キーワード : 行動, マナー, 利用者, 環境配慮, 国立公園, 認識

\section{1. 目的}

自然公園では，利用増加や利用形態の変化が自然環境にもたら す影響が懸念されている。なぜなら，利用圧が自然環境との軋䡚 をもたらすことや，最初のわずかな利用圧の導入で多くの被害が 急激に発現・拡大寸ること，そして，あるタイプの被害は利用の 継続に伴い資源の劣化を招くこと，さらに，それらが経済的利益 や利用者の減少，資源保護の奨励を損なうなど望ましくない結果 をもたらすからである ${ }^{1)}$ 。事実, 自然地域において生態的イン パクト（ゴミや樹木や植物へのダメージ，歩道の広がりや浸食） が利用体験にネガティブな影響をもたらした ${ }^{2,3)}$ 。ネガティブな 影響の増大には，過剰利用だけでなく，誤った利用の影響，利用 マナ一の影響も無視できない ${ }^{4)}$ 。知床での調査から，基本的マナ 一の不足は，快適環境の阻害，自然環境ヘインパクト，新たな利 用形態の出現，危険性の増大に関与することが示された ${ }^{5)}$ 。

自然公園利用において，生態系に変化をもたらす主要因の一つ は人の行動であると同時に，人の行動は，認識（社会的そして心 理的）と動作（社会的そして生物物理的）の相互作用であるとさ れる ${ }^{6)}$ 。環境悪化が人の行動に起因するだけでなく，行動の背後 にそれを制御する心理過程が存在し，一方で環境問題を認識する 心理過程も存在している ${ }^{7)}$ 。そのため, 社会心理学では, 集団で の環境配慮行動の規定要因を明らかにする理論として，合理的行 動理論 ${ }^{8)}$ や計画的行動理論 ${ }^{9)}$ 等の環境配慮行動の意思決定を説 明するモデルを示している。広瀬による合理的行動理論と計画的 行動理論を発展させた二段階モデルでは ${ }^{10)}$, 個人の行動に対する 態度としての「目標意図」が形成される段階と具体的な行動を実 行するにあたっての「行動意図」が形成される段階をへて行動に 至る。しかも，「目標意図」と「行動意図」に影響を及ぼす要因は それぞれ異なるとされる ${ }^{10)}$ 。自然公園利用の場合,「目標意図」 の形成には，自然環境への影響の大きさと影響の発生可能性に対 する環境リスクの認知，污染や破壊の原因が誰あるいは何にある のかという責任帰属の認知，何らかの対処によって問題が解決可
能かどうかという対処有効性の認知が関わる ${ }^{11)}$ 。「行動意図」は 知識や技能, あるいは社会的機会へのアクセス可能性などの実行 可能性, 行動のもたらす結果の便益・コストについての評価, 行 動に対する準拠集団の社会的圧力である社会規範評価によって左 右される ${ }^{12)}$ 。二段階モデルに関しては，「目標意図」と異なる「行 動意図」が生じることに対する説明の適合性が広く認められてい る ${ }^{13)}$ 。一方, 行動意図を持っていても行動しない場合の説明とし て, 二重動機モデルが示された ${ }^{14)}$ 。二重動機モデルでは, 環境に 配慮しようとする目標に基づく意図的な動機的プロセスとしての 目標志向型の意思決定と,「目標意図」「行動意図」に反した行動 を許容してしまう, 非意図的, 反応的な動機的プロセスとしての 状況依存型の意思決定に分け，双方のプロセスが最終的意思決定 に対する影響力の違いから, 認知/態度と行動との不一致が生じ るとされた ${ }^{15)}$ 。

一方，利用者の適切な行動を導出するアプローチとしてガイド や情報提供を通じ，利用に対寸る環境への正確な知識伝授の必要 性に関し多くの指摘があるが $16,17,18)$ ，近年，公園利用の分野にお いて，環境配慮行動に着目した研究が行われている。たとえば, 山本・本郷 ${ }^{11)}$ は広瀬 ${ }^{10)}$ のモデルに基づき，「目標意図」を形成す る認知プロセスに着目した。武は ${ }^{16)}$, 環境配慮活動と環境保全意 識との関連性を示すと同時に，南アルプスの登山者について自然 環境への意識と環境配慮行動との矛盾を指摘している。

そこで本研究の目的として, 環境に配慮したマナーに対する認 識, マナ一の実践, マナ一の実践への負担感に対する利用者への アンケート結果を元に，二段階モデルおよび二重動機モデルを参 考に，利用マナーの改善を図る上で，今後の課題を検討すること とした。

\section{2. 調査方法}

環境に配慮した利用マナ一に関する意識調査を，知床国立公園 (以下，知床）では車両規制を行っている 2000 年と 2001 年に,

*専修大学北海道短期大学多どりの総合科学科 


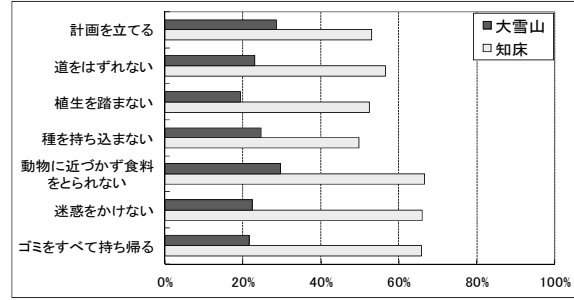

図ー1 環境保全に配慮した利用マナーの認識

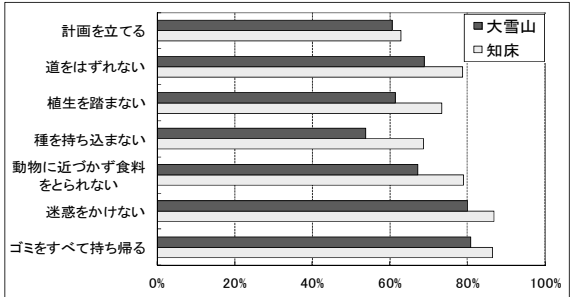

図ー2 環境保全に配慮した利用マナーの実践

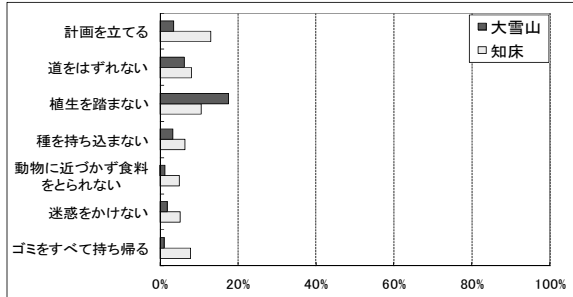

図ー3 環境保全に配慮したマナーに対する負担感
知床五湖およびカムイワッカ湯の滝入口で利用者に対し，および 大雪山国立公園（以下，大雪山）では車両規制を行っている 1999 年, 2000 年, 2001 年に高原沼巡り利用者に対し, 筆者が主体とな り郵送法によるアンケート調査を実施した。知床でのアンケート 配布数は 2000 年が 2477 件, 2001 年が 2864 件, 合計 5341 件で, 回収数は 2000 年が 684 件, 2001 年が 787 件, 合計 1471 件, 回収 率は $27.5 \%$ であった。大雪山でのアンケート配布数は 1999 年が 1213 件, 2000 年が 713 件, 2001 年が 500 件，合計 2426 件で，回 収数は 1999 年が 317 件， 2000 年が 223 件， 2001 年が 152 件，合 計 692 件，回収率は $28.5 \%$ であった。

アンケートの設問項目のうち次の設問を分析対象とした。自然 公園の環境に配慮したマナ一は，利用者による事前の準備と，現 地での対応に分類できることから，事前の準備として “事前にガ イドブックを参考に十分に計画を立てる（以下，計画を立てる)” ことを問うた。次に，現地での対応として，植物への影響につい て，“指定された道を一列で歩き，踏み跡以外に立ち入らない（以 下，道をはずれない)”, “ぬかるみでは，脇の植生を踏まないよう にする (以下, 植生を踏まない)”, “植物の種(たね)を持ち込まな いようにする（以下，種を持ち込まない)”を問うた。動物への 影響については, “キツネ, リス, クマに近づかず食料を取られな いようにする（以下，動物に近づかず食料をとられない)”を問 うた。他者への影響については, “他の利用者の迷惑や邪魔になら ないようにする（以下，迷惑をかけない)”を問うた。持ち込ん だものの処理については, “生ゴミ, 残飯を含めゴミはすべて持ち 帰る（以下，ゴミをすべて持ち帰る)”を問うた。上記の各項目 に対し，“知っている (以下，認識)”, “実施している (以下，実 践)”, “負担になる (以下, 負担感)”の当否について尋ねた。

\section{3. 結果}

\section{（1）回答者属性}

知床では “男性” が $56.4 \%$ ，“20 代以下” が $21.7 \%$ ，“30 代” が $25.0 \%$ ，“40 代”が $22.4 \%$ ，“50 代”が $20.7 \%$, “60 代以上” が $10.3 \%$ であった。構成人数は“単独”が $10.0 \%$, “2 人”が $46.9 \%$, “3〜 4 人”が $31.6 \%$, “5 人以上”が $11.5 \%$ であった。職業は “会 社員” が 41. 8\%，“公務員” が 19.0\%，“主婦”が $17.8 \%$ であつ た。知床への来訪回数は “はじめて”が $56.3 \%$, 居住地は “北海 道”が $31.5 \%$ であった。大雪山では “男性”が $57.3 \%, “ 20$ 代以 下”が 5. $0 \%$, “30 代”が $14.7 \%$, “40 代”が $21.3 \%$, “50 代以上” が $59.0 \%$ あ゙り, 知床に比べて年齢構成が高かった。構成人数は “単独”が $12.7 \%$ ，“2 人”が $49.5 \%$, “3〜4 人”が $20.0 \%$, “5
人以上”が $17.8 \%$ であった。集団構成は “家族・親類” が $54.4 \%$, “友人”が $27.7 \%$ であった。高原沼巡りへの来訪回数は “はじめ て”が 16.8\%, 居住地は “北海道” が 83.7\%であった。知床に比 ベてリピーターや地元である北海道在住の割合が多かった。

\section{（2）環境に配慮した利用マナ一に対する認識}

大雪山に比べて知床では, 環境に配慮した利用マナーを認識し ている利用者の割合が圧倒的に多かった。知床では“動物に近づ かず食料をとられない”，“他人に迷惑をかけない”，“ゴミをす べて持ち帰る”ことを認識している割合は $65 \%$ 前後と最も高く, 最も低い設問でも $49.7 \%$ を示した (図一 1)。一方, 大雪山では, 認識している割合は，どの設問でも $30 \%$ に満たず，“植生を踏ま ない”については最も低く，19.2\%であった（図一 1)。

\section{（3）環境に配慮した利用マナ一の実践}

大雪山に比べて知床では, 実践している利用者の割合がやや多 かった。知床で実践している割合(以下，実践率)の高い（78.7〜 86.9\%) 設問は“他人に迷惑をかけない”，“ゴミをすべて持ち帰 る”，“動物に近づかず食料をとられない”，“道をはずれない” であった (図一2)。一方, 大雪山で実践率の高い (79.9〜80.9\%) 設問は，“ゴミをすべて持ち帰る”，“他人に迷惑をかけない”で あった（図一2）。知床，大雪山いずれも，“植生を踏まない”，

“計画を立てる”，”種をもちこまない”について，他の項目に 比べ実践率は低かった。

\section{（4）環境に二配慮した利用マナ一を実践する負担感}

大雪山，知床いずれも，実践することに負担を感じている利用 者の割合は, ほとんどの設問で $10 \%$ 未満であり, 最高でも $17.5 \%$ であった (図一 3)。

\section{（5）認識，実践，負担感の相互関係}

認識，実践，負担感について，それぞれ “当てはまる（認識し ている, 実践している, 負担になる)” と, 当てはまる以外の回答 (“当てはまらない”あるいは無回答) の組み合わせから8つのパ ターンが生ずる。“当てはまる”場合を○，それ以外の回答を× として表すと, “認識 $\bigcirc$ ・実践 $\bigcirc$ ・負担感 $\times ”$ の利用者や, “認識 $\times$ ・実践 $\bigcirc$ ・負担感 $\times$ ” 利用者の割合が多く, 知床で前者が (図 $-4)$, 大雪山では後者が最も多かった（図一 5 )。

認識の有無よる実践率の違いを比較すると， $\chi^{2}$ 検定の結果, 知 床ではでいずれの設問も有意差を示し，認識している利用者で実 践率が高く(図一6), 大雪山では “植生を踏まない”を除きいず れも有意差が認められ，認識していない利用者で実践率が高かっ た (図一 7)。知床では, 認識の有無による実践率の差は, “計画 を立てる”，“植生を踏まない”，“道をはずれない”，“種を持ち

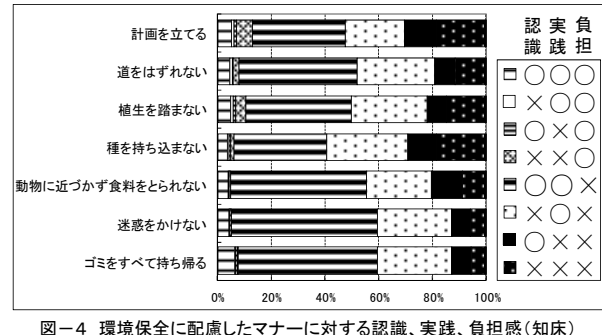

図ー4 環境保全に配慮したマナーに対する認識、実践、負担感(知床)

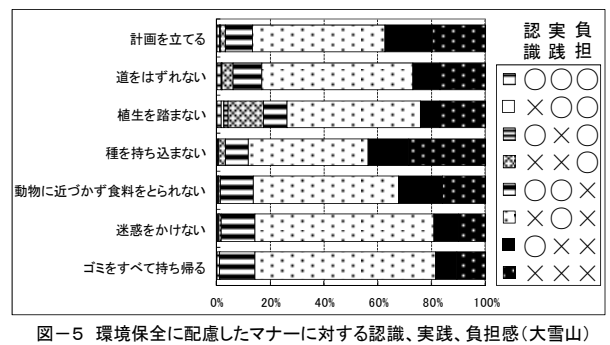
込まない”で大きかった（15.7〜 26.7\%)。大雪山でその差は, “植生を ふまない”を除いて大きかった(19.3 $\sim 33.4 \%$ )。

実践の有無による負担感の違いを比 較すると，知床では， $\chi^{2}$ 検定の結果， 次の設問で有意差が認められた。“植生

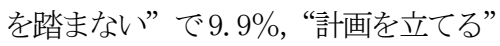
で $8.9 \%$,“道をはずれない”で $5.3 \%$, 


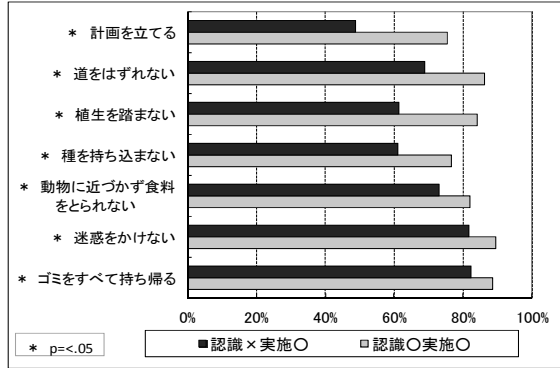

図ー6 認識の有無による実践した割合の違い(知床)

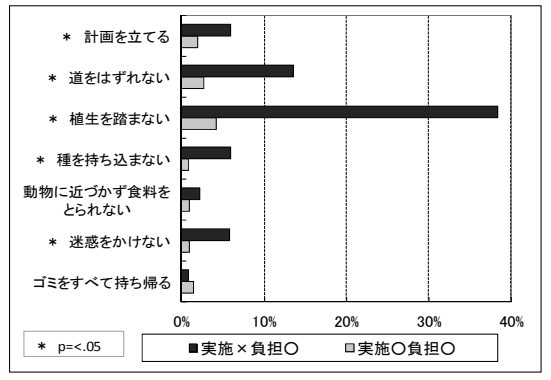

図－9 実践の有無による負担感の違い(大雪山)

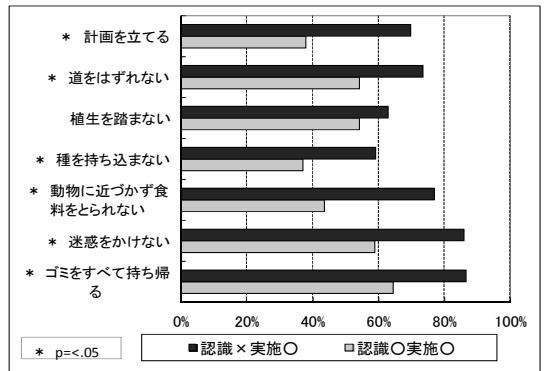

図ー7 認識の有無による実践した割合の違い(大雪山)

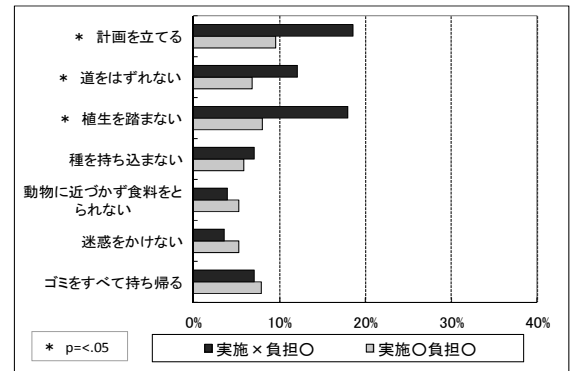

図-8 実践の有無による負担感の違い(知床)
実践する利用者に比べ，実践していない利用者は負担に感じる割 合が多かった（図一8）。大雪山では，“ゴミをすべて持ち帰る” と“動物に近づかず食料をとられない”を除き，すべての設問で 有意差が認められた。実践する利用者に比べ，実践していない利 用者では“植生を踏まない”で $34.2 \%$, “道をはずれない”で $10.8 \%$ ，それぞれ負担に感じる割合が多かった（図一9)。

（6）認識，実践，負担感と，個人属性との関係

知床では各設問に対し年歯や職業と有意な関係がみられた。“計 画を立てる”では年齢や職業以外でも有意な関係がみられた。大 雪山では，知床に比べ有意な関係がみられた属性は，年齢にほぼ 限定された（表一1）。

年齢別に内容をみると，知床では“道をはずれない”，“植生を 踏まない”(図一10)，“種を持ち込まない”, “動物に近づかず食 料をとられない”，“迷迷をかけない”，“ゴミをすべて持ち帰る” (図-11)に関して，50 歳以上で “認識 $\times$ ・実践 $\bigcirc$ ・負担感 $\times ”$ の割合が多く, 20 代から 40 代で “認識 $\bigcirc$ ・実践 $\bigcirc$ ・負担感 $X ”$ が多かった。この傾向は“迷迷をかけない”，“ゴミをすべて持ち 帰る”で顕著であり，若齢層ほど “認識 $○$ ・実践 $\bigcirc$ ・負担感 $\times ”$ の割合が多く，高齢層ほど少なかった。

大雪山では“道をはずれない”, “植生を踏まない”（図一12), “種を持ち込まない”，“迷迷をかけない”(図一13)に関して, 20

\section{4. 考察 \\ 図一 1 から，自然公園の環境に配慮した利用マナーを認識して} いる割合は知床で高く, 大雪山で低い結果となった。図一 2 から, マナーを実践している割合は，大雪山に比べ知床でやや高い傾向 を示したものの，認識している割合ほど顕著な差はなかった。実 践の割合に比べ，認識の割合で調査地間で違いが大きい背景の一 つ，大雪山では高齢者およびリピーターが多いことから，設問 内容であるマナ一に対する認識が，環境配慮への社会的関心が問 題視されていない頃と変わらぬままであるためではないか, と推 察される。

知床, 大雪山いずれも, 図一 2 から, “ゴミをすべて持ち帰る”， “他人に迷惑をかけない”について, 実践している割合が多く, 逆に, “植生を踏まない”, “計画を立てる”, “種をもちこまない” について，他の設問に比べ実践している割合は少なかった。背景 として，“植生を踏まない”，“計画を立てる”，“種をもちこまな い”ことを的確に行うには必要な知識や情報を要することから,

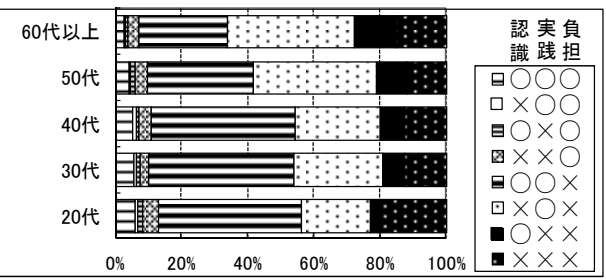

図-10 年齢別にみた、植生を踏まないことへの対応 (知床)

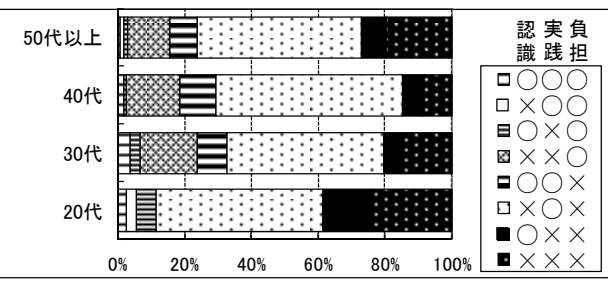

図-12 年齢別にみた、植生を踏まないことへの対応(大雪山)

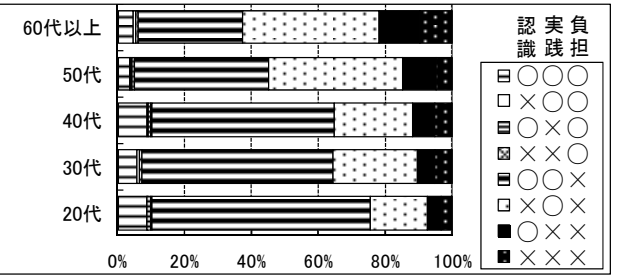

図-11 年齢別にみた、ゴミをすべて持ち帰ることへの対応(知床)

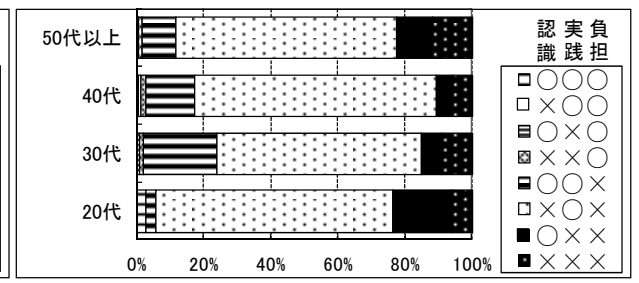

図-13 年齢別にみた、迷惑をかけないことへの対応(大雪山) これらの情報が利用者に十分に周 知されていないことや，環境配慮 意識および行動の必要性に対する 理解が不足している点もあると考 えられる。環境配慮行動に関わる 課題として対処方法に関する知識 や実践的な知識の不足は深刻とさ れており ${ }^{19)}$, 利用者に対する環境 配慮行動の具体的な実践行為をど のように利用者に伝え，理解を得 るかについて今後の課題である。 また, 図一6と 7 から, 認識の 有無の違いによって実践率が異な り, 知床では認識を有する利用者 で実践率が高く，大雪山では逆に 認識していない利用者で実践率が 
高かった。知床については認識の高さが実践率の高さに反映した とみられる。大雪山については，要因を推定することが今回の調 查ではできなかった。

図一3から，環境に配慮した利用マナ一を行うことに負担感を 抱く利用者は少なく, 環境保全行動に対する抵抗感は少ないと判 断される。しかし, 図一8と9から, 知床, 大雪山ともに, “計画 を立てる”，“道を外れない”, “植生を踏まない”について，実践 していない利用者で負担に感じる割合が多いことが示された。こ のことは，環境配慮行動を規定する要因として，今井が指摘した 20)，負担の関与を再確認する結果となった。

認識，実践，負担感に対する回答から８通りの組み合わせにタ イプ分けされ，図一 4 と 5 から，「認識し実践し負担感のない利 用者や，「認識していないが実践し負担感のない利用者の割合が 多く，知床で前者が，大雪山では後者の割合が最も多かった。環 境に配慮したマナ一を事前に知っていたことは環境に配慮した 「目標意図」の改善に影響し, 負担感を覚えないようにすること が「行動意図」の阻害要因を抑制し，結果的に，環境配慮行動の 実践を広めることにつながると考えられる。

環境配慮行動をより多くの利用者が実践するようにするには, 二段階モデル ${ }^{10)}$ や重動機モデル ${ }^{14)}$ で示された考え方を参考に, 各タイプの特性を理解した上で対策を検討寸る必要があると考え られる。まず，「認識がない，負担感のない」タイプについて，実 践したとしても, それは意識的判断でなく非意図的対応 ${ }^{21)}$ と推察 される。改善策の立案には，その非意図的対応が，情報不足，あ るいは教育欠如によるものなのかを見定め,「目標意困」の改善に つながる管理方法を検討しなければならない。次に，「認識し，実 践しない」タイプについて，負担感の有無に関わらず，環境配慮 に手を抜いた行動を許容するプロセスとして理解されることから 15,22) , 状況依存型の意思決定による影響と考えられる。そのため, 環境配慮が乏しい行為が社会的に批判される行為であり, 多くの 人々が環境配慮した行動をしていることを周知することによって, 判断基準の変化を捉えることが重要である。次に，「認識し，実践 している」タイプについて，これを持続させるためには，負担感 を減ずる手だてを講ずるとともに，第三者がこの行為に対する肯 定的評価をサポートしている姿勢を明示する必要がある。認識が なく, 実践し, 負担感のある」タイプについて, 負担感を生ずる 原因および負担感を感じつつも実践を阻害しなかった心理状況を 明らかにすることが求められる。「認識がなく, 実践せず, 負担感 のある」タイプについて，何が原因で負担感を覚えるのか, どの 程度の負担感があるのかといった情報を整理するとともに，環境 保全に対する関心を引くきっかけづくりに配慮すべきである。

実務上，利用者をタイプ毎にセグメント化できないので，上記 の検討を総合化したうえで対策を立案，実行し，実効性を学術調 査によりフィードバックさせることが不可欠である。

一方，表- 1 から，認識，実践，負担感と個人属性との関係に つて，知床では年齢と職業，大雪山では年齢との関連性が示さ れた。この結果は，世代間で，環境保全に対する認識や実践，負 担感が異なることを示した。背景には環境保全に対寸る考え方, 対応が時代ともに変化したことがあると考えられる。一方，20代 で，知床では環境配慮行動にポジティブであり，逆に大雪山では ネガティブな態度を示寸傾向が示された。原因の一つとしては, 事例対象地の立地特性に対する受け止め方の違いによると思われ るが，原因を特定できななった。

社会心理学を専門とする今井は ${ }^{20)}$, 環境配慮行動を阻害する要 因として，実行するためのコスト，実行してもメリットが見えに くい，実行するための責任が分散している，実行しない他者から の影響を受けてしまう，監視されることが少ないので自律的実行 が求められる点などを指摘している。自然公園での利用はいずれ
もこれらの条件に該当するケースが多いと考えられる。また，広 瀬 ${ }^{10)}$ が示した社会心理学的モデルを援用すれば, 土壌や動植物資 源への利用圧との関係は, 資源保全と個別的な消費の対立が問題 となる資源枯渇型のジレンマとみなすことができ，ゴミ投棄につ いては環境の污染防止と個別の廃棄との対立，環境污染型のジレ ンマとみなすことができる。自然公園における利用行為の改善を 図る上で, 社会心理学における認知・行動モデルを参考に調査研 究を進めることは，環境に配慮した利用マナ一の改善にとどまら ず，利用者に対する環境情報や環境教育の仕組みに新たな視点を 提供しうると考えられる。

\section{補注及び引用文献}

1) Cole, D.N. (1995): Wilderness management principles: Science, logical thinking or personal opinion? : Trends 32 (1), 6-9. <http://canback.com/archive/ farrell.pdf>, 更新日不明, 2011.8.28 参照

2) Lynn, N. \& Brown, R. (2003): Effects of recreational use impacts on hiking experiences in natural areas: Landscape and Urban Planning, 64, 77-87.

3）小林昭裕(2005)：大雪山国立公園の登山道の生態的インパクトに対す る利用者の評価に関する基礎的研究：ランドスケープ研 68(5), $737-742$.

4）小林昭裕 (2006A）：自然公園の過剰利用対策としての収容力の扱い及び 適正利用を図る計画手順上の課題：環境情報科学論文集 20 , 171-176.

5）小林昭裕 (2006B)：知床国立公園の利用適正化に向けた計画策定内容 及び手法に関する一考察: ランドスケープ研究 69(5), 635-640.

6) Alessa, L., Bennett, S. M., \& Kliskey, A.D. (2003): Effects of knowledge, personal attribution and perception of ecosystem health on depreciative behaviors in the intertidal zone of Pacific Rim National Park and Reserve: Journal of Environmental Management 68, 207-218.

7）安藤清志 (2009)：環境配慮行動と社会心理学-社会系規範情報の効果: 東洋大学 Eco-Philosophy Vol. 4, 69-77.

8) Aizen, I. \& M. Fishbein (1977) : Attitude - behavior relations A theoretical analysis and review of empirical research: Psychological Bulletin No.84, 888-918.

9) Ajzen, I (1991) : The theory of planned behavior: Organizational Behavior and Human Decision Process No.50, 179-221.

10) 広瀬幸雄 (1994）：環境配慮行動の規定因について：社会心理学研究 $10(1), \quad 44-55$.

11）山本清龍，本郷哲郎(2006)：青木が原樹海の利用者がもつ自然公園イ メージと環境配慮意識の関係性に関する研究：環境情報科学論文集 20, 153-158.

12) 西尾チヅル (2010)： 個人の環境配慮行動における社会規範の影響: 環境情報科学 $39(1) ， 29-33$.

13)村上一真(2009)：森林ボランティア活動の意思決定プロセスに関する 構造分析：環境情報科学論文集 23,315-320.

14) Ohtomo, S. \& Hirose, Y. (2007): The dual process of reactive and intentional decision-making involved in eco-friendly behavior: Journal of Environmental Psychology 27, 117-125.

15）参考資料 社会的価值行動の脳科学的分析〜神経倫理学研究の現状及 び理論的展望一，蟹池 陽一〈www. caa. go. jp/seikatsu/keizaijikken /nousan1-1. pdf〉, 更新日不明, 2011.9.10 参照

16) 武正憲 (2008) : カヌーイストを対象とした野外レクリエーション活動 家の環境保全意識と環境配慮行動の関係 : ランドスケープ研究 71(5), 689-694.

17) 国立・国定公園の指定及び管理運営に関する検討会(2007)：国立・国 定公園の指定及び管理運営に関する提言一時代に応える自然公園を求 めて - : 〈http://www. env. go. jp/press/file_view. php?serial=9288 \&houid=8136>, 更新日不明, 2009.9.10 参照

18) 小林昭裕 (2010) : 知床国立公園における情報に対する利用者の認知や 要望および, これらに関与する要因 : ランドスケープ研究 73 (5) , 493-498

19）土井美枝子(2010)：わが国の環境教育における意識と行動に関する既 往研究の系譜: 広島大学マネジメント研究 No. 11, 99-110.

20) 今井芳昭 (2008)：環境配慮行動を促すための社会心理学的アプロー チ: 東洋大学 Eco-Philosophy Vol. 2, 107-128.

21）環境配慮の態度と行動〈ocw. nagoya-u. jp/files/127/1ect5. pdf〉, 更 新日不明, 2011.8.28 参照

22) 環境行動など社会的価值に対する行動に関する 脳科学的な視点 www. caa. go. jp/seikatsu/keizaijikken/nou2-1. pdf〉, 更新日不明, 2011.9.22 参照 